\title{
EVALUATION OF THE EFFECTS OF COCONUT OIL ON SOME BIOCHEMICAL PARAMETERS IN ALBINO RATS
}

\author{
F. A. James ${ }^{1 *}$, N. Boisa ${ }^{1}$, N. Nwachoko ${ }^{2}$ and O. S. Bull ${ }^{1}$ \\ ${ }^{1}$ Chemistry Department, Rivers State University, Port Harcourt, Nigeria. \\ ${ }^{2}$ Biochemistry Department, Rivers State University, Port Harcourt, Nigeria. \\ *Corresponding Author: jacodaqueens@yahoo.com +2348036181395 \\ Received 19 August 2020; accepted 12 October 2020, published online 30 January 2021
}

\begin{abstract}
Coconut oil from coconut kernel is a source of natural cooking oil for most people in tropical countries. This study was undertaken to evaluate the effects of coconut oil on some biochemical, haematological and histological parameters in albino rats. Two phases of experiment with four groups of male albino rats each consisting of five rats weighing about $180-200 \mathrm{~g}$ were used for this study. Phase 1 of the experiment involves feeding of albino rats with commercial rodent chow mixed with coconut oil, coconut oil supplemented diet (COSD) while phase 2 experimental rats were treated with coconut oil orally. Group 1 served as the control for both phases of treatment, groups 2, 3 and 4 were treated with $3 \mathrm{ml} / \mathrm{kg}, 6$ $\mathrm{ml} / \mathrm{kg}$ and $12 \mathrm{ml} / \mathrm{kg}$ of COSD and coconut oil respectively for 4 weeks. Result of both phases of experiment showed significant increase $(\mathrm{p} \leq 0.05)$ in serum concentrations of AST, ALP and ALT levels. Also, the result showed that the levels of urea and creatinine decreased significantly when compared with the control group. Haematological results showed that levels of haemoglobin and PCV for both phases of treatment decreased significantly $(\mathrm{p} \leq 0.05)$ compared with the control group. Total protein for COSD treatment phase showed a significant increase while total protein for coconut oil $(\mathrm{CO})$ oral administration treatment phase decreased significantly for only group 4 albino rats when compared with control. Histopathological results showed normal liver hepatocytes in the treated albino rats except for some albino rats with microvesicular steatosis. This study has also shown that coconut oil within the dosage administered cause mild inflammation of the liver in some of the albino rats.
\end{abstract}

Keywords: Coconut Oil, Enzyme, Urea, Creatinine, Haematological, Histopathological

\section{INTRODUCTION}

Toxicity is the extent to which a substance or a particular mixture of substances can damage an organism [1]. Toxicants are substances that are detrimental to an organism; these organisms may be plants or animals [2]. Pathways through which toxicants enter the body of an organism is by absorption through the skin, ingestion through the mouth and inhalation through the nose [3] where they exert biochemical effect such as cell membrane disruption, malfunction of protein biosynthesis by their action on DNA, enzyme inhibition, disruption of lipid metabolism resulting in excess lipid accumulation (fatty liver) and disruption of carbohydrate metabolism $[4,5]$. The outrageous use of food substandard in chemical composition may lead to toxic effects [6].

Coconut from Cocos nucifera palm family is an essential part of food and source of revenue in most tropical countries [7]. Coconut oil from coconut kernel is one of the edible oils on the rise as a dietary supplement and functional food in the emergent functional food market [8]. The likely impact of coconut oil on human health due to its high concentration in saturated fats has been a subject of discussion by researchers especially nutritionist and other health managers. Some have noted that the saturated fats present in coconut oil could contribute to atherosclerosis and cardiovascular diseases (CVD) $[9,10]$. As a food item, coconut oil offers countless health remunerations to humans, such as antifungal, antibacterial, antimicrobial, antiviral and many more [11]. Coconut oil has a long shelf life and it is used in baking industries, processed food, infant formulae, pharmaceuticals, cosmetics and as hair oil [7].

\section{MATERIALS AND METHODS}

Collection of Coconut Kernel: Matured coconuts were purchased at the Mbiama market in Ahoada West Local Government Area of Rivers State, Nigeria. The coconuts were identified and authenticated by Dr. Stanley Dimkpa as Cocos 
nucifera (dwarf specie) at Crop Science Department of Rivers State University, Port Harcourt, Nigeria.

\section{Extraction of Coconut oil}

The matured coconut kernel was de-shelled to obtain the endosperm using a paired knife, the endosperm was washed, weighed and later blend with water in a food processor to obtain coconut milk. The coconut milk was filtered from the blend coconut with a cheese cloth over a wide - mouth container and refrigerated for 24 hours. After 24 hours, the milk was scooped out and subjected to mild heating using an electric hot plate cooker at $60^{\circ} \mathrm{C}$ for 30 minutes until the water content was completely evaporated. Further, the protein coagulates to release oil and the residue was repeatedly filtered with a cheese cloth to obtain pure coconut oil [12].

\section{Experimental Design}

Thirty - five male albino rats weighing between 180 - $200 \mathrm{~g}$ were purchased from the Department of Biochemistry animal house in the University of Port Harcourt. The albino rats were allowed access to commercial rodent chow and clean drinking water ad libitum for one - week acclimatization before treatment that lasted for four weeks.

The albino rats were divided into four groups of five rats each for two phases of treatment. These groups were labeled 1, 2, 3, and 4 .

Group 1 albino rats were treated with water and rodent chow; they served as control for both phases of treatment.

Phase 1 albino rats were treated with coconut oil supplemented diet (COSD). Rodent feed was mixed with coconut oil. The albino rats were treated with the mixed feed at $3 \mathrm{ml} / \mathrm{kg}, 6 \mathrm{ml} / \mathrm{kg}$ and $12 \mathrm{ml} / \mathrm{kg}$ body weight for groups 2, 3 and 4 respectively [13].

Phase 2 albino rats were administered with coconut oil by oral gavage at $3 \mathrm{ml} / \mathrm{kg}, 6 \mathrm{ml} / \mathrm{kg}$ and $12 \mathrm{ml} / \mathrm{kg}$ body weight for groups 2, 3 and 4 respectively [13].

\section{Blood Sample Collection}

At the end of the experiment, albino rats were sacrificed and blood samples collected from each albino rat in the control and treatment groups in EDTA anticoagulant sample bottles for biochemical and haematological analysis. The liver was excised and stored in separate sample bottles containing 10 $\mathrm{ml}$ of formaldehyde solution for histopathological studies [14].

\section{Serum Biochemical \& Haematological Analysis}

Biochemical and haematological analysis was carried out to evaluate the effects of coconut oil on serum concentrations of AST, ALT, ALP, total protein, albumin, urea, creatinine, PCV and haemoglobin using a spectrophotometer AD23.

\section{Histopathological Studies}

The liver was dehydrated in concentrations of ethanol, cleared in xylene and implanted in paraffin wax. Paraffin sections 5 microns $(\mu)$ thick were made and mounted on glass slides. The glass slides were double stained with hematoxylin and eosin $(\mathrm{H}$ $\&$ E stains) and viewed under a light microscope (x400 magnification). All alterations from the normal structure were recorded. Photomicrographs were attained at diverse magnifications to show the alterations in liver of the albino rats for the control and experimental group.

\section{Statistical Analysis}

All data were statistically expressed as mean \pm standard error mean (SEM). One - way analysis of variance (ANOVA) was carried out on the results using SPSS Version 21.0. Differences between control and treatment groups were considered significant at $\mathrm{p} \leq 0.05$ using the Duncan's post hoc test.

RESULTS AND DISCUSSION

Table 1: Effect of Coconut Oil on Enzyme Activities

\begin{tabular}{|c|c|c|c|c|c|c|c|}
\hline \multirow[b]{2}{*}{ Groups } & \multirow[b]{2}{*}{$\begin{array}{l}\text { Treatment } \\
(\mathrm{ml} / \mathrm{kg})\end{array}$} & \multicolumn{3}{|c|}{ Coconut Oil Supplemented Diet } & \multicolumn{2}{|c|}{ Oral Administration } & \multirow[b]{2}{*}{$\begin{array}{l}\text { ALT } \\
\text { (U/L) }\end{array}$} \\
\hline & & $\begin{array}{l}\text { AST } \\
\text { (U/L) }\end{array}$ & $\begin{array}{l}\text { ALP } \\
\text { (U/L) }\end{array}$ & $\begin{array}{l}\text { ALT } \\
\text { (U/L) }\end{array}$ & $\begin{array}{l}\text { AST } \\
\text { (U/L) }\end{array}$ & $\begin{array}{l}\text { ALP } \\
\text { (U/L) }\end{array}$ & \\
\hline 1 & Control & $52.6 \pm 3.43^{\text {bdf }}$ & $33.8 \pm 0.84^{\mathrm{df}}$ & $16.6 \pm 1.51^{\mathrm{f}}$ & $52.6 \pm 3.43^{\text {bdf }}$ & $33.8 \pm 0.84^{\mathrm{df}}$ & $16.6 \pm 1.52^{\mathrm{bdt}}$ \\
\hline 2 & 3 & $57.6 \pm 1.82^{* a}$ & $34.4 \pm 1.67^{\mathrm{adf}}$ & $16.4 \pm 1.14^{\text {af }}$ & $64.8 \pm 3.49^{* a f}$ & $37.2 \pm 1.92^{* a}$ & $19.0 \pm 2.55^{* a}$ \\
\hline 3 & 6 & $58.0 \pm 1.0^{* \mathrm{c}}$ & $37.6 \pm 1.51^{* \mathrm{bcf}}$ & $17.2 \pm 1.48^{\mathrm{cf}}$ & $60.6 \pm 2.70 * \mathrm{c}$ & $39.2 \pm 2.39^{* \mathrm{c}}$ & $20.2 \pm 2.17^{* \mathrm{c}}$ \\
\hline 4 & 12 & $58.8 \pm 2.05 *^{\mathrm{e}}$ & $39.4 \pm 0.89^{* b d e}$ & $22.4 \pm 2.07^{* b d e}$ & $58.2 \pm 3.11^{* \mathrm{be}}$ & $40.0 \pm 4.12^{* \mathrm{e}}$ & $20.6 \pm 1.34^{* \mathrm{e}}$ \\
\hline
\end{tabular}

Values are expressed as mean \pm standard deviation of mean (SEM) for $n=5$. Values with different superscript letters in the same rows are significantly different at the 0.05 level $(p \leq 0.05)$. 
Table 2: Effect of Coconut Oil on Kidney Functions

\begin{tabular}{|c|c|c|c|c|c|c|c|}
\hline & & \multicolumn{3}{|c|}{ Coconut Oil Supplemented Diet } & \multicolumn{3}{|c|}{ Oral Administration } \\
\hline Groups & $\begin{array}{l}\text { Treatment } \\
(\mathrm{ml} / \mathrm{kg})\end{array}$ & $\begin{array}{l}\text { Urea } \\
(\mathrm{mmol} / \mathrm{L})\end{array}$ & $\begin{array}{l}\text { Creatinine } \\
(\mathrm{mmol} / \mathrm{L})\end{array}$ & $\begin{array}{l}\text { Albumin } \\
(\mathrm{g} / \mathrm{L})\end{array}$ & $\begin{array}{l}\text { Urea } \\
(\mathbf{m m o l} / \mathrm{L})\end{array}$ & $\begin{array}{l}\text { Creatinine } \\
(\mathrm{mmol} / \mathrm{L})\end{array}$ & $\begin{array}{l}\text { Albumin } \\
(\mathrm{g} / \mathrm{L})\end{array}$ \\
\hline $\mathbf{1}$ & control & $6.2 \pm 0.31^{\mathrm{b}}$ & $146.0 \pm 1.41^{\mathrm{bd}}$ & $37.2 \pm 3.03^{\mathrm{b}}$ & $6.2 \pm 0.31^{\text {bdf }}$ & $146.0 \pm 1.41^{\mathrm{bdf}}$ & $37.2 \pm 3.03^{\mathrm{b}}$ \\
\hline 2 & 3 & $5.4 \pm 0.18^{\text {*adf }}$ & $130.2 \pm 3.96^{* \mathrm{adf}}$ & $42.0 \pm 2.55^{* \mathrm{adf}}$ & $5.5 \pm 0.31^{* \mathrm{a}}$ & $134.6 \pm 2.88^{* a f}$ & $40.2 \pm 1.79^{* a d f}$ \\
\hline 3 & 6 & $5.9 \pm 0.13^{\mathrm{bcf}}$ & $136.8 \pm 2.17^{* \mathrm{bcf}}$ & $40.6 \pm 1.14^{* \mathrm{bc}}$ & $5.6 \pm 0.11^{*_{\mathrm{c}}}$ & $136.6 \pm 1.82^{*_{\mathrm{c}}}$ & $37.2 \pm 1.30^{\mathrm{bc}}$ \\
\hline 4 & 12 & $6.2 \pm 0.36^{\text {bde }}$ & $146.8 \pm 2.05^{\mathrm{bde}}$ & $40.4 \pm 4.10^{* \text { be }}$ & $5.7 \pm 0.08^{* e}$ & $138.2 \pm 1.64^{* \mathrm{be}}$ & $37.0 \pm 1.87^{\text {be }}$ \\
\hline
\end{tabular}

Values are expressed as mean \pm standard deviation of mean (SEM) for $n=5$. Values with different superscript letters in the same rows are significantly different at the 0.05 level $(\mathrm{p} \leq 0.05)$.

Table 3: Effect of Coconut Oil on Total Protein and Haematology

\begin{tabular}{|c|c|c|c|c|c|c|c|}
\hline \multicolumn{5}{|c|}{ Coconut Oil Supplemented Diet } & \multicolumn{3}{|c|}{ Oral Administration } \\
\hline Groups & $\begin{array}{l}\text { Treatment } \\
(\mathrm{ml} / \mathrm{kg})\end{array}$ & $\begin{array}{l}\text { T.P } \\
(\mathrm{g} / \mathrm{L})\end{array}$ & $\begin{array}{l}\text { PCV } \\
(\%)\end{array}$ & $\begin{array}{l}\text { Hb } \\
(\mathrm{g} / \mathrm{dL})\end{array}$ & $\begin{array}{l}\text { T.P } \\
\text { (g/L) }\end{array}$ & $\begin{array}{l}\text { PCV } \\
(\%)\end{array}$ & $\begin{array}{l}\text { Hb } \\
(\mathrm{g} / \mathrm{dL})\end{array}$ \\
\hline 1 & control & $60.6 \pm 3.43^{\text {bdf }}$ & $37.8 \pm 3.9^{\mathrm{bdf}}$ & $12.6 \pm 0.14^{\mathrm{bdf}}$ & $60.6 \pm 3.43^{\text {bf }}$ & $37.8 \pm 3.9^{\mathrm{bdf}}$ & $12.6 \pm 0.14^{\mathrm{bd}}$ \\
\hline 2 & 3 & $69.0 \pm 2.12^{* a}$ & $33.0 \pm 1.73^{* a d f}$ & $11.8 \pm 0.23^{* a}$ & $63.4 \pm 1.52^{* a d f}$ & $34.8 \pm 2.49^{* a}$ & $11.6 \pm 0.25^{* a}$ \\
\hline 3 & 6 & $68.2 \pm 2.05^{* \mathrm{c}}$ & $34.8 \pm 0.84^{* \mathrm{bc}}$ & $11.7 \pm 0.30^{* \mathrm{c}}$ & $60.6 \pm 2.41^{\mathrm{bcf}}$ & $35.0 \pm 1.58 * \mathrm{cf}$ & $11.9 \pm 0.28^{*_{\mathrm{c}}}$ \\
\hline 4 & 12 & $67.6 \pm 1.52^{* \mathrm{e}}$ & $35.0 \pm 1.58^{* \mathrm{be}}$ & $11.8 \pm 0.31^{* \mathrm{e}}$ & $57.8 \pm 1.79^{* \text { bde }}$ & $36.6 \pm 1.95^{\text {*de }}$ & $12.3 \pm 0.23^{\mathrm{e}}$ \\
\hline
\end{tabular}

Values are expressed as mean \pm standard deviation of mean (SEM) for $n=5$. Values with different superscript letters in the same rows are significantly different at the 0.05 level $(p \leq 0.05)$.

\section{HISTOLOGY}

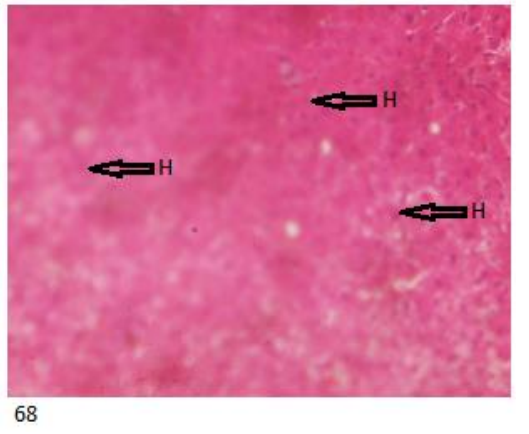

1a-Normal hepatocyte cells $(\mathrm{H})$.

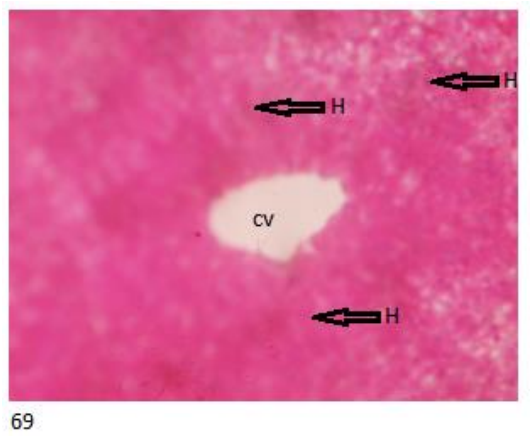

$1 \mathrm{~b}-$ Normal hepatocyte cells $(\mathrm{H}) \quad$ 1c - Normal hepatocyte cells $(\mathrm{H})$.

Plate 1a-1c: Photomicrographs of the liver of albino rats for the control group 


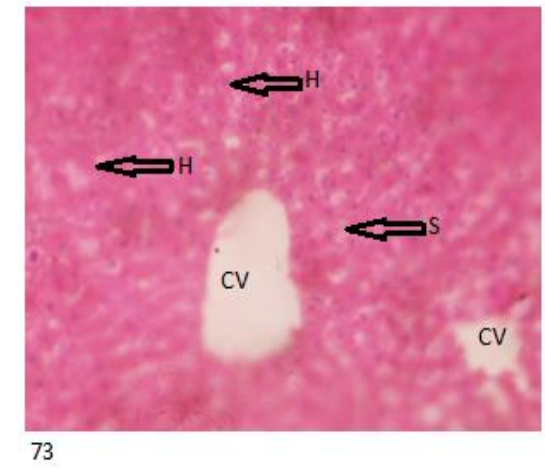

2a-Normal hepatocyte cells $(\mathrm{H})$. Sinusoids (S).

Patent central vein $(\mathrm{CV})$.

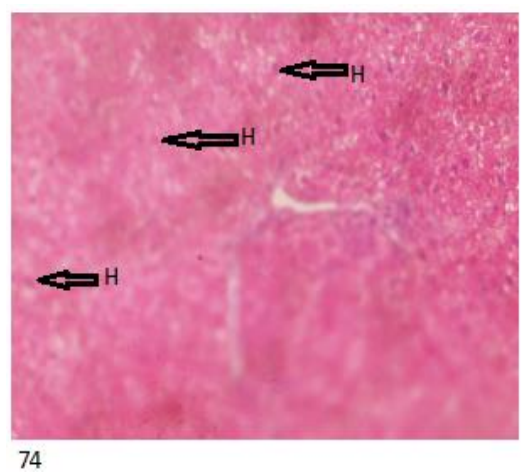

2b-Normal hepatocyte cells $(\mathrm{H})$. 2c-Normal hepatocyte cells $(\mathrm{H})$. Sinusoids (S).

Patent central vein $(\mathrm{CV})$.

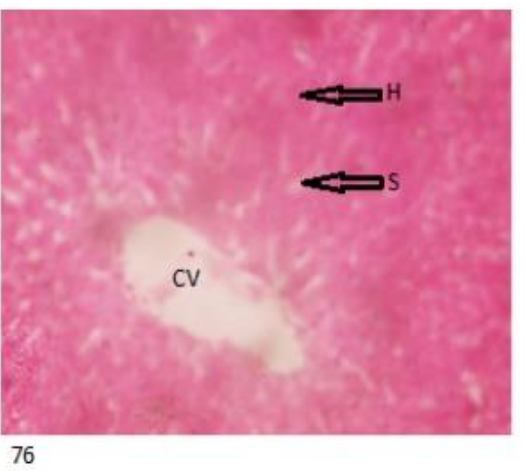

Plate 2a - 2c: Photomicrographs of the liver of albino rats for COSD group 2

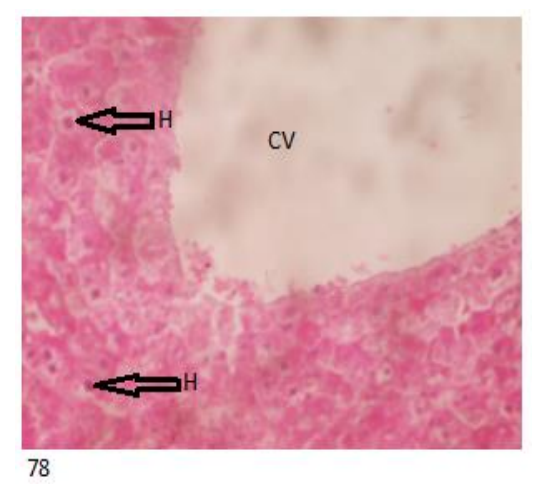

3a-Normal hepatocyte cells $(\mathrm{H}) .3 \mathrm{~b}-\mathrm{N}$

Patent central vein $(\mathrm{CV})$.

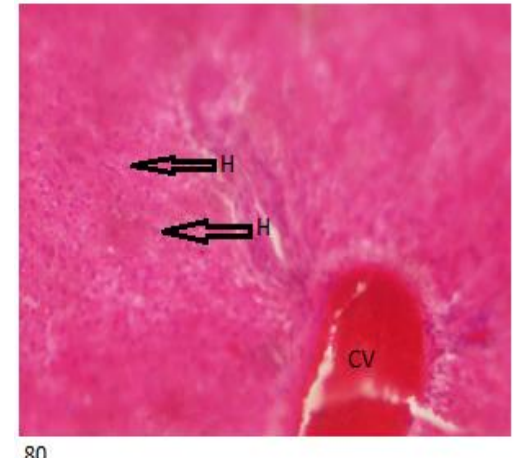

80

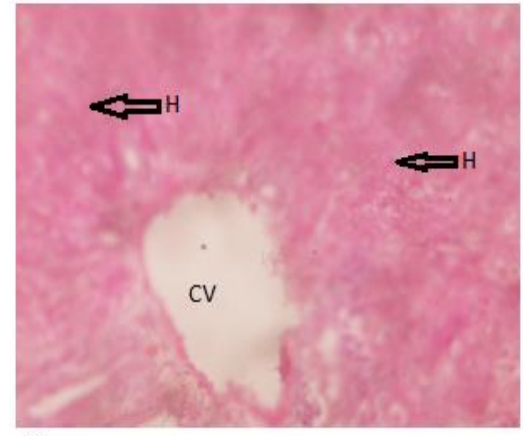

81

$3 \mathrm{c}-$ Normal liver hepatocytes $(\mathrm{H})$. Patent central vein $(\mathrm{CV})$.

\section{Plate 3a-3c: Photomicrographs of the liver of albino rats for COSD group 3}

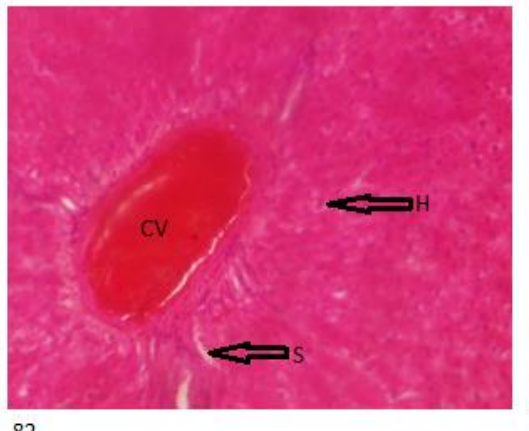

$4 \mathrm{a}-$ Normal hepatocyte cells $(\mathrm{H})$ Sinusoids (S)

Congested central vein $(\mathrm{CV})$

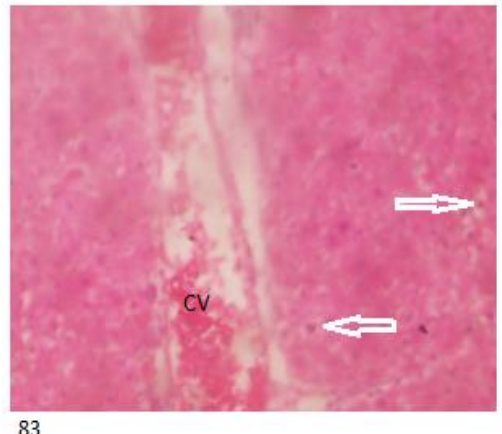

83

$4 \mathrm{~b}-$ Hepatocyte cells with microvesicular steatosis

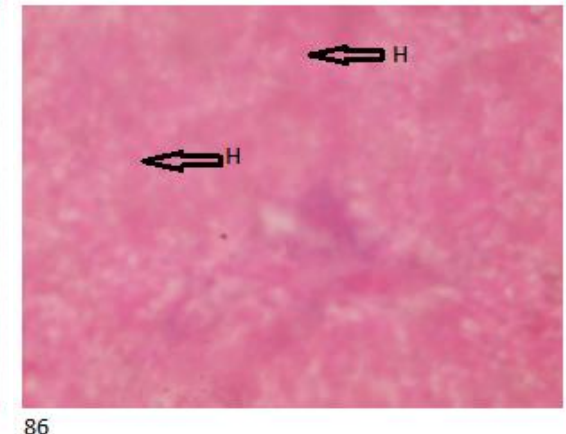

$4 \mathrm{c}-$ Normal hepatocyte cells $(\mathrm{H})$.

Plate 4a-4c: Photomicrographs of the liver of albino rats for COSD group 4 


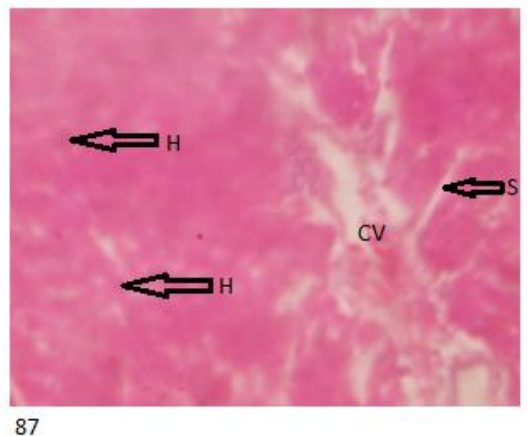

5a-Normal hepatocyte cells $(\mathrm{H})$. Sinusoids (S).

Patent central vein $(\mathrm{CV})$.

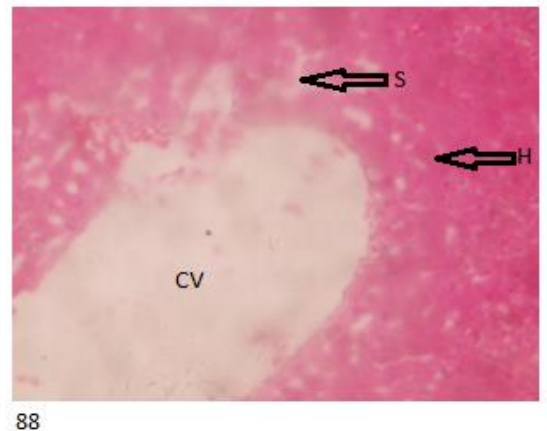

$5 \mathrm{~b}-$ Normal hepatocyte cells $(\mathrm{H})$. Sinusoids (S).

Patent central vein $(\mathrm{CV})$.

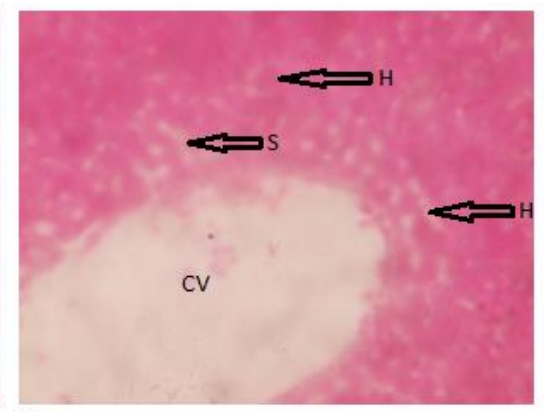

89

$5 \mathrm{c}-$ Normal hepatocyte cells $(\mathrm{H})$. Sinusoids (S).

Patent central vein $(\mathrm{CV})$.

Plate 5a-5c: Photomicrographs of the liver of albino rats for coconut oil oral administration group 2

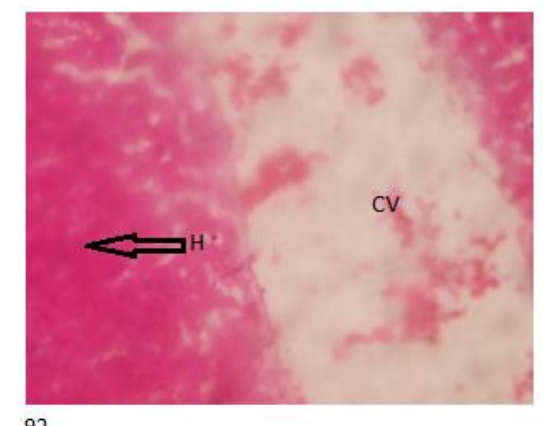

$$
92
$$

$6 \mathrm{a}$-Normal hepatocyte cells $(\mathrm{H})$. Patent central vein $(\mathrm{CV})$.

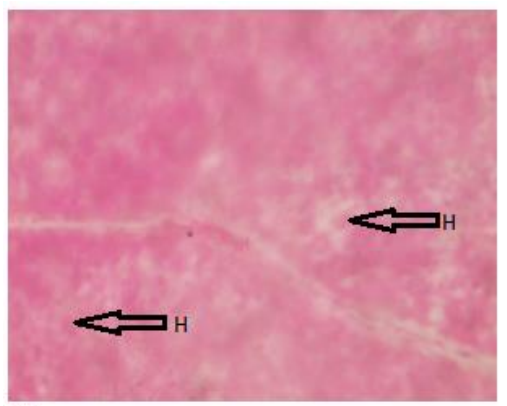

\section{3}

$6 \mathrm{~b}-$ Normal hepatocyte cells $(\mathrm{H})$

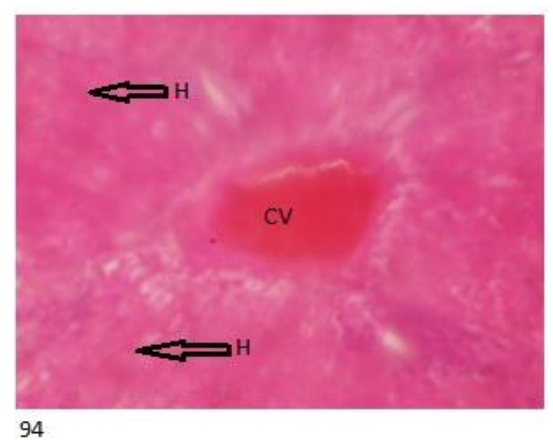

94

Plate 6a-6c: Photomicrographs of the liver of albino rats for coconut oil oral administration group 3

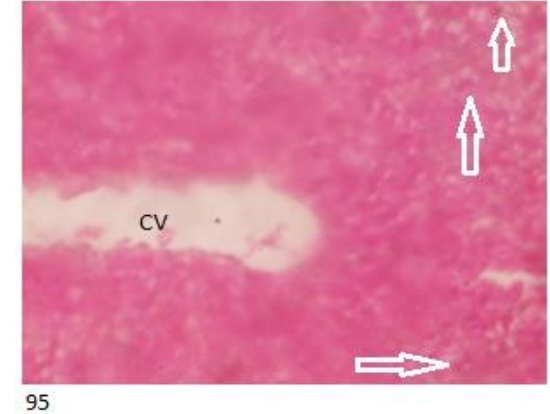

$7 \mathrm{a}-$ Hepatocyte cells with microvesicular steatosis.

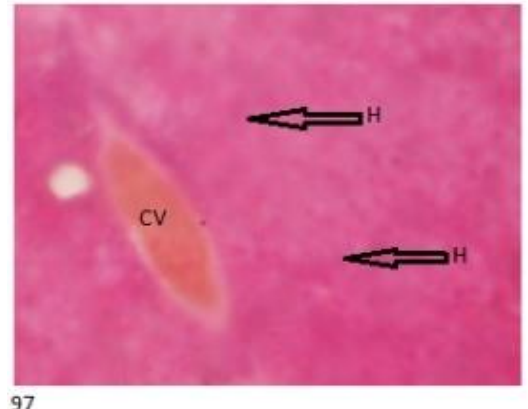

$7 \mathrm{~b}$-Normal hepatocyte cells $(\mathrm{H})$. Congested central vein $(\mathrm{CV})$.

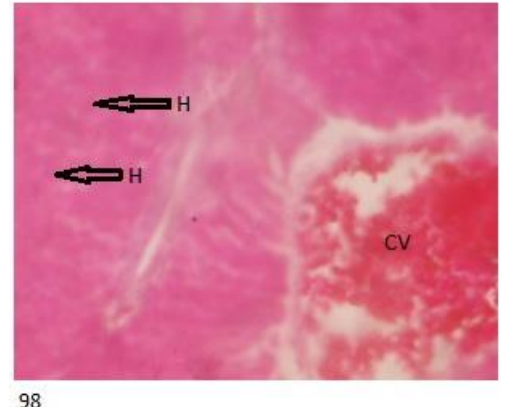

7c-Normal hepatocyte cells $(\mathrm{H})$. Congested central vein $(\mathrm{CV})$.

Plate 7a-7c: Photomicrographs of the liver of albino rats for coconut oil oral administration group 4 


\section{DISCUSSION}

The result of the effect of coconut oil on the enzyme activities of albino rats treated with coconut oil supplemented diet (COSD) and coconut oil (CO) oral administration are showed on Table 1. The result indicated that there was a significant increase $(p \leq 0.05)$ in AST, ALP and ALT levels for both phases of treatment when compared with the control. The statistical increase in the levels of these enzymes agrees with findings in persons who consumed coconut oil for 8 weeks as these persons who consumed coconut oil had increase in these enzyme activities [15]. Table 2 shows results of the effect of coconut oil on kidney functions of the treated albino rats. When the filtration in the kidney is poor, creatinine blood levels increases [16]. In this study, the urea and creatinine blood levels for both treatment phases showed a significant decrease compared to the control group. This may infer that the kidneys of the albino rats used for this study were not affected. There was a significant $(\mathrm{p} \leq 0.05)$ increase in albumin levels for COSD treated groups compared with the control. Albumin levels for the coconut oil (CO) oral administration treatment phase increased significantly for only group 2 rats while group 4 rats had insignificant decrease compared with the control rats. The effect of coconut oil on total protein and haematological parameters are on Table 3, the result revealed that there was a significant $(p \leq 0.05)$ increase of total protein levels in the COSD treated phase compared with the control. Total protein levels for the coconut oil (CO) oral administration treated phase revealed a significant increase in group 2 albino rats while that of group 4 albino rats revealed that there was a significant decrease in total protein when compared with the control albino rats. PCV levels revealed a significant decrease for both treatment phases compared with the control group. Haemoglobin levels of the treated rats indicated a significant $(\mathrm{p} \leq 0.05)$ decrease for both treated phases compared with the control except for coconut oil (CO) oral administration group 4 albino rats where the decrease is insignificant.

Plate 1a $-7 \mathrm{c}$ showed the photomicrographs of the histological result of the liver of albino rats used for this study. The histological result of albino rat liver for the control group in plate $1 \mathrm{a}-$ $1 \mathrm{c}$ revealed that the albino rats had normal liver with regular hepatocytes, sinusoids and prominent central vein as indicated with the black arrow. Plate $2 a-2 c(C O S D$ group 2$)$ liver sections appeared normal with regular hepatocytes, sinusoids and central vein for the albino rats in this group. Plate $3 a-3 c$ (COSD group 3) revealed normal liver with regular hepatocytes for plate $3 \mathrm{a}, 3 \mathrm{~b}$ and $3 \mathrm{c}$ albino rats. Plate $4 \mathrm{a}-4 \mathrm{c}$ (COSD group 4), plate $4 \mathrm{a}$, and $4 \mathrm{c}$ liver sections appeared histologically normal with regular hepatocytes, sinusoids and central vein while plate $4 \mathrm{~b}$ had abnormal liver hepatocyte as indicated with the white arrow. Plate $5 \mathrm{a}-5 \mathrm{c}$ (Coconut oil oral administration group 2). Normal liver cells with regular hepatocytes, sinusoids and central vein was discovered in plate $5 \mathrm{a}, 5 \mathrm{~b}$ and $5 \mathrm{c}$ as indicated with the black arrow. Plate $6 a-6 c$ (Coconut oil oral administration group 3), it was revealed that the liver of albino rats in this group are normal with regular hepatocytes and central vein. Plate $7 \mathrm{a}-7 \mathrm{c}$ (Coconut oil oral administration group 4), an abnormal liver hepatocyte with microvesicular steatosis was discovered in plate $7 \mathrm{a}$ as indicated with the white arrow while plate $7 \mathrm{~b}$ and $7 \mathrm{c}$ revealed that the liver of the albino rats are normal with regular hepatocytes and a congested central vein. Microvesicular steatosis is usually an acute liver disorder histologically regarded as numerous tiny lipid vesicles in the hepatocyte that leaves the nucleus at the middle of the cell [17]. It's certainly not a major damage to the liver [18]; clinically it can be linked with a rise in serum amino transferase levels $[18,19]$.

\section{CONCLUSION}

This study has shown that coconut oil within the administered concentrations cause mild inflammation of the liver in some of the experimental rats.

\section{REFERENCES}

[1] D. L. Kasper, S. F. Anthony, L. L. Dan, L. J. Jameson, L. Joseph and L. H. Stephen (2015). Harrison's principles of internal medicine, $9^{\text {th }}$ edition. United States: McGraw - hill education. 
[2] S. E. Manahan (1992). Toxicological chemistry. $\quad 2^{\text {nd }}$ edition, lewis publishers/CRC press. Boca raton, FL.

[3] F. J. Gonzalez (1998). The study of xenobiotic metabolizing enzymes and their role in toxicity in vivo using targeted gene disruption, Toxicology Letters, 102, 161-166.

[4] P. Millburn (1995). The fate of xenobiotics in mammals: biochemical processes. Progress in Pesticide Biochemistry and Toxicology, 8, 1-86.

[5] S. E. Manahan (2000). Environmental science, technology and chemistry. Boca raton: CRC press LLC.

[6] P. K. Mukherjee (2002). Quality control of herbal drugs, Pharmaceutical Publishers, 113.

[7] F. M. D. Bruce (2004). The coconut oil miracle. USA $4^{\text {th }}$ Edition, $1-7$.

[8] A. M. Marina, Y. B. Che-Man and I. Amin (2009). Virgin coconut oil: emerging functional food oil, Trends in Food Science and Technology, 20(10), 481- 487.

[9] C. Dayrit and H. B. Calleja (2003). Professorial lecture on coconut oil: atherogenic or not? Philippine Journal of Cardiology, (3), 97-103.

[10] M. F. Piepoli, A. W. Hoes and S. Agewall (2016). "2016 European guidelines on cardiovascular disease prevention in clinical practice: the sixth joint task force of the European society of cardiology and other societies on cardiovascular disease prevention in clinical practice (constituted by representatives of 10 societies and by invited experts): developed with the special contribution of the European association for cardiovascular prevention and rehabilitation (EACPR)". European Heart Journal, $72-78$.

[11] F. Bruce (2009). Coconut oil miracle. Adventure works press, Philippines.

[12] R. K. Agarwal and S. J. D. Bosco (2017). Extraction processes of virgin coconut oil, MOJ Food Processing and Technology, 4(2), 54 - 56.
[13] N. Boisa, N. Nwachoko, O. S. Bull and F. A. James (2020). Physical composition, proximate, phytochemical and impact of coconut oil on lipid profile of albino rats, IOSR Journal of Applied Chemistry, 13(7), 51-56.

[14] A. Mann, A. Thompson, N. Robbins and A. L. Blomkalns (2014). Localization, identification and excision of murine adipose depots, Journal of Visualized Experiments, 12(4), 94.

[15] S. Chinwong, D. Chinwong and $M$. Ampica (2017). Daily consumption of virgin coconut oil increases high-density lipoprotein cholesterol levels in healthy volunteers: A randomized crossover trial, Evidence-based Complementary and Alternative Medicine, 1-8.

[16] K. Md. M. Hassan, N. Tamanna and Md. A. Haque (2017). Biochemical and histopathological profiling of wistar rat treated with Brassica napus as a supplementary feed. Food Science and Human Wellness, 7(2018), 77-82.

[17] F. Bissuel, F. Bruneel, F. Habersetzer, D. Chassard, L. Cotte, M. Chevallier, J. Bernuau, J.C. Lucet and C. Trepo (1994). Fulminant hepatitis with severe lactate acidosis in HIV-infected patients on didanosine therapy. Journal of Internal Medicine, 235, 367-371.

[18] A. Boyd, O. Cain, A. Chauhan and G. James-Webb (2020). Review: medical liver biopsy on background, indications, procedures and histopathology, open access: Frontline Gastroenterology, 11, 40-47.

[19] L. Miele, A. Liguori, G. Marrone, M. Biolata, C. Araneo, F. G. Vaccaro, M. Gasbarrini and A. Grieco (2017). Fatty liver and drugs: The two sides of the same coin. European Review for Medical and Pharmacological Sciences, 21(1), 86-94. 